Jurnal DIALOGIKA Manajemen dan Administrasi

Homepage: https://ejurnal.unma.ac.id/index.php/dialogika

Vol. 1 No. 1, Oktober 2019, halaman: 11 18

E-ISSN: 2720-9865, P-ISSN: 2716-3563

https://doi.org/10.31949/dialogika.v1i1.162

\title{
PERAN PENGEMBANGAN SUMBER DAYA MANUSIA DAN BUDAYA KERJA TERHADAP KINERJA PEGAWAI
}

\author{
Asep Suhada \\ Program Studi Administrasi Publik, Fakultas Ilmu Sosial dan Politik Universitas Majalengka \\ e-mail korespondensi: denaberseka7@gmail.com
}

Disubmit Agustus 2019 , Diterima September 2019, Diterbitkan Oktober 2019

Submitted August 2019, Accepted September 2019, Published October 2019

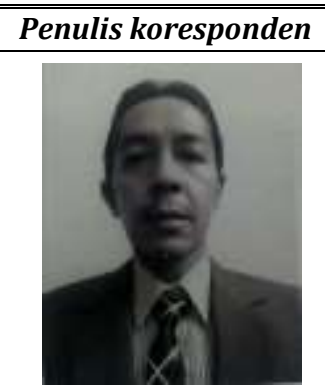

Jurnal DIALOGIKA diterbitkan oleh Program Pascasarjana Administrasi Publik Universitas Majalengka \begin{abstract}
This study aims to examine descriptively about the application of human resource management and work culture as well as examine verification about the effect of the application of human resources and work culture on employee performance partially and together. The research method uses descriptive and verification, the population consists of employees of PDAM Majalengka Branch with a total sampling technique. Source of data used are primary and secondary data with correlation and regression analysis techniques. Descriptive research results indicate that the application of human resource management, work culture, and performance in PDAM' is not optimal. Verification research results prove that the application of human resource managementand work culture has a significant and partially significant effect.
\end{abstract}

Keywords: Development, Human Resources, Work Culture, Employee Performance.

\begin{abstract}
Abstrak
Penelitian ini bertujuan untuk mengkaji secara deskriptif tentang penerapan manajemen sumber daya manusia dan budaya kerja serta mengkaji secara veripikatif tentang pengaruh penerapan sumber daya manusia dan budaya kerja terhadap kinerja pegawai secara parsial dan bersama. Metode penelitian manggunakan deskriptif dan veripikatif, populasi terdiri atas pegawai PDAM Cabang Majalengka dengan teknik total sampling. Sumber data yang digunakan berupa data primer dan sekunder dengan teknik analisis korelasi dan regresi. Hasil penelitian deskriptif menunjukkan bahwa penerapan manajemen sumber daya manusia, budaya kerja, dan kinerja di PDAM belum optimal. Hasil penelitian veripikatif membuktikan bahwa penerapan manajemen sumber daya manusia dan budaya kerja berpengaruh signifikan secara parsial dan simultan.
\end{abstract}

Kata kunci: Pengembangan, Sumber Daya Manusia, Budaya Kerja, Kinerja Pegawai

\section{PENDAHULUAN}

Perusahaan Daerah Air Minum (PDAM) merupakan salah satu badan usaha milik daerah. Dalam pelaksanaannya di bawah pengawasan, pengelolaan, dan pembinaan pemerintah daerah, di manasebagian besar modalnya berasal dari pemerintah daerah. Salah satu tujuan dari PDAM adalah melaksanakan pembangunan daerah melalui pelayanan kepada masyarakat, khususnya dalam penyediaan air bersih. Untuk dapat memberikan pelayanan yang baik kepada pelanggan, pegawai ditutut untuk melaksanakan kewajiban sesuai dengan tugas dan fungsinya dalam arti berkinerja tinggi.

Kinerja adalah suatu ukuran untuk melihat apakah seseorang telah mencapai target pekerjaan dengan baik atau belum, sehingga bisa juga merupakan catatan hasil yang dilakukan atas fungsi pekerjaan tertentu dalam kurun waktu tertentu. Dalam melihat kinerja pegawai, berkaitan juga dengan tingkat kehadiran, semangat, motivasi, bahkan keluhan-keluhan yang dialami dan masalah yang dihadapi. 
(Sudarmanto, 2014); Jatmika, 2017).

Dalam memberikan pelayanan kepada masyarakat atau konsumen, pegawai PDAM Cabang Majalengka diharapkan mampu mengerjakan tugas sesuai target pekerjaan, cepat, tepat, dan berkualitas. Dalam mengatasi hambatan, seperti kebocoran pipa saluran air, menyediakan air yang berkualitas, dan penyelesaian pengaduan yang responship sangat diperlukan. Tetapi fenomena yang terjadi di lapangan, kinerja pegawai belum memenuhi harapan masyarakat, terutama pengguna jasa PDAM di wilayahnya. Rendahnya kinerja pegawai ditandai dengan masih banyaknya keluhan pelanggan, baik dalam mengatasi keluhan, dan pemenuhan air yang berkualitas.

Rendahnya kinerja pegawai PDAM bukan hal yang mustahil, karena terdapat beberapa faktor yang mempengaruhinya. Dari hasil observasi awal ditemukan informasi bahwa faktor yang paling urgent saat itu adalah pengembangan sumber daya manusia yang belum terencana dengan baik dan budaya kerja yang kurang kondusif. Dari beberapa penelitian terdahulu, terbukti bahwa pengembangan sumber daya manusia (MSDM) berpengaruh terhadap kinerja pegawai (Jatmiko dan Andarwati, 2017; Masirete, 2011), Panjaitan, 2017). Demikian juga halnya dengan budaya kerja, beberapa penelitian terdahulu telah membuktikan bahwa budaya kerja berpengaruh terhadap kinerja pegawai (Sudarman, 2018; Sunjaya, 2017; Mahanani, 2014).

Dengan demikian, sebagai solusi untuk mengatasi masalah rendahnya kinerja pegawai PDAM, dalam penelitian ini peneliti melakukan kajian terhadap pengaruh pengembangan sumber daya manusia dan budaya kerja terhadap kinerja pegawai.

Pengembangan sumber daya manusia dalam suatu organisasi penting dilakukan dalam upaya meningkatkan kompetensi dan fungsi sumber daya manusia (SDM) yang pada gilirannya akan meningkatkan kualitas kerja para pegawai.

Dalampelaksanaannya harus mendapat perhatian yang sungguh-sungguh dan dirancang sebaik mungkin, karena dengan perencanaan yang matang dan akurat pelaksanaan pengembangan sumber daya manusia akan berjalan lancar sesuai dengan tujuan organisasi (Dipang, Ludfia, 2013; Haromain, 2013).

Pengembangan sumber daya manusia, termasuk di dalamnya pendidikan dan pelatihan baik secara individu maupun kelompok, dilakukan melalui bermacammacam cara. Bagi pegawai yang baru pertama kali masuk kerja, diberi kesempatan untuk memperoleh keteram- pilan baru sesuai bidang tugas yang akan menjadi tanggung jawabnya. Bagi pegawai yang sudah lama mengabdi, diberi pelatihanuntuk meningkatkan pengetahuan, keterampilan, wawasan, sikap dalam rangka menyesuaikan dengan perkem- bangan dunia kerja dan perkembangan teknologi. Pada intinya, pengembangan SDM untuk membentuk personal yang berkualitas agar berkinerja tinggi melalui pelatihan, pendidikan, pembinaan, recruitment, perubahan sistem, kesempatan, dan penghargaan. Apabila program pelatihan digabung dengan pengembangan SDM akan menghasilkan produktivitas organisasi serta mampu meningkatkan efektivitas dan efisiensi pekerjaan yang erat kaitannya dengan kinerja pegawai dan berbagai masalah dalam pengelolaan SDM yang muncul dari sistem sistem aktivitas manusia. (Novia, 2017; Setiobudi, Eko, 2017; Rahmat, 2017).

Faktor lain yang berpengaruh terhadap kinerja karyawan PDAM adalah budaya kerja. Budaya kerja adalah kesimpulan dari asumsiasumsi dasar yang dipelajari sebagai hasil dari memecahkan masalah yang ada di luar maupun di dalam organisasi (Schein,2008). Budaya kerja adalah nilai-nilai yang dikembangkan dalam waktu lama oleh pendiri dan anggota, disosialisasikan kepada anggota baru agarditerapkan dalam aktivitas organisasi sehingga akan membentuk cara pandang, sikap, dan perilaku serta menjadi komitment individu dan membentuk etos kerja yang akan berpengaruh terhadap kinerja individu. Penerapan nilai-nilai tersebut akan mencipatakan iklim yang membawa kenyamanan bagi anggota organisasi. (Sunjaya at.all,2017; Sudarman, 2018). Kaitan antara budaya kerja dan kinerja pegawai hasil penelitian Iqbal (2017) menunjukkan bahwa budaya kerja berpengaruh signifikan terhadap kinerja pegawai. 
Dari telaah terhadap pendapat para ahli dan hasil penelitian, pengembanganSDM dan budaya kerja berpengaruh terhadap kinerja pegawai, Kinerja dapat diartikan sesuatu yang dicapai, prestasi yang diperlihatkan, atau kemampuan kerja. Kemampuan kerja biasanya berkaitan dengan alat kerja. (KKBI, daring). Dalam organisasi, baik swasta maupun negeri memiliki peranan penting dalam mendukung kinerja organisasi. Dalam menghadapi tuntutan jaman, di mana perubahan sosial terus terjadi maka perbaikan kinerja pegawai dalam memberikan pelayanan masyarakatmenjadi isu yang paling penting untuk segera ditangani. Kinerja pegawai yang baik, dapat menunjukkan seberapa jauh tingkat kemampuan organisasi dalam memberikan pelayanan kepada pelanggan/masyarakat. (Sunjaya, 2017; Sudarman, 2018; Panjaitan, 2017).

Berdasarkan latar belakang dan telaah pendapat ahli, penelitian ini bertujuan untuk mengetahui pengaruh pengembangan sumber daya manusia (SDM dan budaya kerja terhadap kinerja pegawai, dengan paradigma penelitian sebagai berikut:

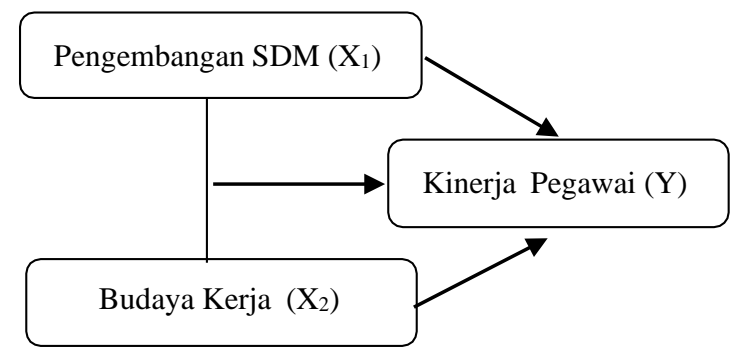

Gambar : 1. Paradigma Penelitian

\section{METODE PENELITIAN}

Penelitian ini berlokasi di PDAM Cabang Majalengka selama tiga bulan. Metode penelitian menggunakan deskriptif dan verifikatif dengan pendekatan kuantitatif. Teknik pengumpulan data berupa penyebaran kuesioner kepada responden sebanyak 85 orang yang terdiri atas pegawai PDAM, penetapan banyak sampel menggunakan teknik total sampling. Untuk melengkapoi data yang belum tercover oleh kuesioner digunakan juga observasi dan wawancara. Sumber data terdiri atas dua macam, yaitu data primer yang diperoleh langsung dari responden dan data sekunder berupa informasi yang bersumber dari pihak lain yang mendukung dan relevan. Data yang diperoleh dianalisis dengan pendekatan statistik parametrik, korelasi dan regresi, pengujian hipotesis menggunakan t-tes, Ftest dan uji determinasi.

\section{HASIL DAN PEMBAHASAN Hasil penelitian}

Data utama yang diperoleh dalam penelitian ini berupa jawaban responden atas kuesioner yang disebarkan. Data tersebut diolah dan dianalisis melalui dua cara, yaitu analisis deskriptif dan analisis verifikatif. Analisis deskriptif diawali dengan penyusunan kriteria penilaian, mulai dari menghitung nilai kumulatif, menghitung persentase kumulatif, sampai diperoleh klasifikasi kriteria penilaian persentase sebagai berikut;

Tabel 1 Persentase Kriteria Penilaian

\begin{tabular}{ccc}
\hline No & Persentase & Kriteria Penilaian \\
\hline 1 & $20-35,99$ & Sangat kurang baik \\
2 & $36-51,99$ & Kurang baik \\
3 & $52-67,99$ & Cukup baik \\
4 & $68-83,99$ & Baik \\
5 & $84-100$ & Sangat baik \\
\hline
\end{tabular}

Untuk mengukur tiap-tiap variabel penelitian, disusun kuesioner didasarkan atas teori yang melandasinya. Untuk pengembangan SDM, disusun kuesioner sebanyak sebelas item, untuk budaya kerja disusun kuesioner sebanyak duabelas item, dan untuk kinerja pegawai disusun kuesioner sebanyak empatbelas item. Setelah diolah dan dianalisis, diperoleh hasil sebagaimana disajikan pada tabel 2 berikut ini:

Tabel 2, Rekap Jawaban Responden Variabel Pengembangan SDM $\left(\mathrm{X}_{1}\right)$, Budaya Kerja $\left(\mathrm{X}_{2}\right)$, dan Kinerja Pegawai (Y).

\begin{tabular}{crcc}
\hline Variabel & Rata-rata & Persentase & Kategori \\
\hline X1 & 321,45 & $75,63 \%$ & Baik \\
X2 & 334,92 & $78,80 \%$ & Baik \\
Y & 328,78 & $77,36 \%$ & Baik \\
\hline
\end{tabular}

Sumber: Hasil Penelitian, data diolah.

Dari data pada tabel 2, dapat dijelaskan bahwa variabel pengembangan SDM memperoleh skor rata-rata $321,45(75,63 \%)$ dalam kategori baik, variabel budaya kerja 
memperoleh skor rata-rata 334,92 $(78,80 \%)$ dalam kategori baik, dan variabel kinerja pegawai memperoleh rata- rata skor 328,78 $(77,36 \%)$ dalam kategori baik. Dengan demikian, secara umum semua variabel penelitian berada pada kondisi baik, hanya terdapat kelemahan pada indikator tertentu menurut persepsi responden, dilihat dari perolehanpersentase terkecil.

Analisis verifikatif dengan teknik statistik, dilakukan untuk mengetahui pengaruh dari variabel bebas terhadap variabel terikat baik secara sendiri-sendiri maupun bersama. Analisis dilakukan dengan pendekatan statistik parametrik, di mana sebelumnya diperlukan terlebih dahulu pengujian persyaratan analisis. Antara lain, uji validitas dan reliabilitasinstrumen serta uji normalitas data. Hasil uji validitas item kuesioner disajikan pada tabel 3 di bawah ini.

Tabel 3, Hasil Hji Validitas Item

\begin{tabular}{|c|c|c|c|c|}
\hline \multirow[t]{2}{*}{ Variabel } & \multicolumn{2}{|c|}{$\mathrm{r}$-hitung } & \multirow[b]{2}{*}{$r$-tabel } & \multirow{2}{*}{ Ket. } \\
\hline & terkecil & terbesar & & \\
\hline $\mathrm{X}_{1}$ & 0,564 & 0,765 & 0,300 & Valid \\
\hline $\mathrm{X}_{2}$ & 0,543 & 0,815 & 0,300 & Valid \\
\hline Y & 0,365 & 0,678 & 0,300 & Valid \\
\hline
\end{tabular}

Sumber: Hasil penelitian, data diolah

Data pada tabel 3 menunjukkan bahwa semua hasil pengujian untuk variabel penelitian, $r$-hitung $>r$-tabel yang beratrti semuanya valid. Berikut disajikan hasil pengujian reliabilitas instrumen terhadap variabel penelitian menggunakan alpha cronbach.

Tabel 4. Hasil Pengujian Reliabilitas

\begin{tabular}{lccc}
\hline Variabel & r-hitung & r-tabel & Ket. \\
\hline X1 & 0,909 & 0,700 & Reliabel \\
X2 & 0,915 & 0,700 & Reliabel \\
Y & 0,865 & 0,700 & Reliabel \\
\hline
\end{tabular}

Sumber: Hasil penelitian, data diolah

Data pada tabel 4 menunjukkan bahwa instrumen untuk semua variabel yang diteliti reliabel, karena $\mathrm{r}^{-}$-hitung $>\mathrm{r}{ }^{-}$-tabel, , sehingga dapat dilanjutkan kepada proses analisis berikutnya. Pengujian normalitas data dilakukan untuk mengetahui apakah data tersebar normal atau tidak. Pengujian menggunakan grafik Normal Probability Plot. Dari hasil pengujian diketahui semua data normal, karena sebaran data mengikuti garis diagonal.

Setelah persyaratan analisis selesai, kemudian dilanjutkan dengan pengujian hipotesis menggunakan t-test dan $F$-test. Hasilnya disajikan pada tabel 5 di bawah ini.

Tabel 5, Hasil Uji Hipotesis.

\begin{tabular}{lcccl}
\hline Hipotesis & $(\mathrm{r})$ & $\begin{array}{l}\mathrm{t} \text {-hitung/ } \\
\mathrm{F}_{\text {-hitung }}\end{array}$ & $\begin{array}{l}\mathrm{t} \text {-tabel/ } \\
\mathrm{F}_{\text {-tabel }}\end{array}$ & Kesimpulan \\
\hline $\operatorname{pyx}_{1}$ & 0,835 & 6,192 & 1,671 & $\begin{array}{l}\mathrm{H}_{0} \text { ditolak, } \mathrm{H}_{1} \\
\text { diterima. }\end{array}$ \\
$\operatorname{pyx}_{2}$ & 0,820 & 5,463 & 1,671 & $\begin{array}{l}\text { Hoditolak, } \mathrm{H}_{1} \\
\text { diterima. }\end{array}$ \\
$\operatorname{pyx}_{1} \mathrm{x}_{2}$ & 0,888 & 137,072 & 3,130 & $\begin{array}{l}\mathrm{H}_{0} \text { ditolak, } \mathrm{H}_{1} \\
\text { diterima. }\end{array}$ \\
\cline { 3 - 4 } & & & &
\end{tabular}

Sumber: Hasil penelitian, data diolah

Hipotesis pertama, terdapat pengaruh pengembangan SDM terhadap kinerja pegawai $\left(\right.$ pyx $\left._{1}\right)$. Dari hasil pengujian diperoleh nilai koefisien korelasi ( $\mathrm{r}$ ) sebesar 0,835 , dan untuk mengetahui tingkat signifikansinya dilakukan uji $t$, ternyata $t$ hitung $(6,192)$ lebih besar dari t-tabel $(1,671)$ yang berarti pengembangan SDM berpengaruh secara signifikan terhadap kinerja pegawai.

Hipotesis kedua, terdapat pengaruh budaya kerja terhadap kinerja pegawai $\left(\right.$ pyx $\left._{2}\right)$. Dari hasil pengujian diperoleh nilai koefisien korelasi (r) sebesar 0,820, dan untuk mengetahui tingkat signifikansinya dilakukan uji $t$, ternyata t-hitung $(5,463)$ lebih besar dari t-tabel $(1,671)$ yang berarti budaya kerja berpengaruh secara signifikan terhadap kinerja pegawai.

Hipotesis ketiga, terdapat pengaruh pengembangan SDM dan budaya kerja terhadap kinerja pegawai $\left(\operatorname{pyx}_{1 \times 2}\right)$. Dari hasil pengujian diperoleh nilai koefisien korelasi (r) sebesar 0,888, dan untuk mengetahui tingkat signifikansinya dilakukan uji $F$, ternyata F-hitung $(137,072)$ lebih besar dari F-tabel $(3,130)$ yang berarti pengembangan SDM dan budaya kerja secara bersama berpengaruh signifikan terhadap kinerja pegawai. Uji determinasi dilakukan untuk mengetahui besaran pengaruh variabel bebas terhadap variabel terikat, dihitung dengan rumus $K D=r^{2} \times 100$. Diperoleh hasil sebagai berikut.

Koefisien determinasi untuk $\mathrm{pyx}_{1}$, dengan koeffisien korelasi (r) sebesar 0,835 diperoleh $\mathrm{R}^{2}$ sebesar 0,6972 atau 69,72\%. Artinya, pengembangan SDM berpengaruh terhadap kinerja pegawai sebesar 69,72\%. 
$\operatorname{pyx}_{1}$

Koeffisien determinasi untuk $\mathrm{pyx}_{2}$, dengan koeffisien korelasi (r) sebesar 0,820 diperoleh $\mathrm{R}^{2}$ sebesar 0,6724 atau 67,24\%. Artinya, budaya kerja berpengaruhterhadap kinerja pegawai sebesar 67,24\%. pyx 1 .

Koeffisien determinasi untuk $\mathrm{pyx}_{1} \mathrm{x}_{2}$, dengan koeffisien korelasi (r) sebesar 0,888 diperoleh $\mathrm{R}^{2}$ sebesar 0,7885 atau 78,85\%. Artinya pengembangan SDM dan budaya kerja secara bersama berpengaruh sigifikan terhadap kinerja pegawai PDAM Cabang Majalengka, sisanya $(21,15 \%)$ dipengaruhi faktor lain yang tidak dimasukan ke dalam model.

Dari hasil uji regresi berganda, diperoleh persamaan regresi yang merupakan model persamaan garis untuk melihat pengaruh variabel $X$ terhadap variabel $\mathrm{Y}$, diperoleh persamaan sebagai berikut :

$$
\begin{aligned}
Y & =a+b_{1} X_{1}+b_{2} X_{2} \\
& =10,856+0.502 X_{1}+0.411 X_{2}
\end{aligned}
$$

Persamaan ini berarti bahwa : a) Setiap peningkatan satu skor pengembangan sumber daya manusia berpengaruh terhadap sebesar 0.502 skor dengan asumsi variabel budaya kerja nilainya konstan; b) Setiap peningkatan satu skor variabel budaya kerja berpengaruh terhadap peningkatan variabel kinerja pegawai sebesar 0.411 skor dengan asumsi variabel pengembangan sumber daya manusia nilainya konstan. Dari hasil analisis tersebutdiketahui dengan jelas, bahwa nilai regresi variabel pengembangan sumber daya manusia $(0,502)$ lebih besar dibanding nilai regresi variabel budaya kerja $(0,411)$.

\section{Pembahasan}

Hasil penelitian secara deskriptif menujukkan bahwa setiap variabelpenelitian berada pada kondisi baik. Hal ini dapat menjelaskan bahwa variabel pengembangan sumber daya manusia yang semula dianggap rendah, ternyata tidak mencakup keseluruhan pengembangan, karena berdasarkan persepsi responden telah berjalan dengan baik, terutama pada indikator nomor sebelas yaitu tetang "perusahaan memberikan sanksi bagi pegawai yang bekerja kurang baik”. Namun memang masih terdapat aspek yang lemah menurut persepsi responden, karena nilai yang diperoleh paling kecil, yaitu tentang kesadaran pegawai dalam mengikuti workshop.

Untuk variabel budaya kerja, kondisinya baik dalam arti pegawai PDAM Cabang Majalengka memiliki budaya kerja yang mendukung terlaksananya tugas dengan baik. Hal ini seakan berlawanan dengan hasil observasi awal yang menyatakan bahwa budaya kerja rendah, ternyata bukan pada keseluruhan budaya kerja melainkan hanya pada aspek tertentu. Antara lain pada indikator nomor lima dalam hal "mengatasi kendala kerja" yang rendah menurut persepsi responden dengan nilai persentase paling rendah. Untuk variabel kinerja pegawai, pada observasi awal ditemukan fenomena rendahnya kinerja, ternyata tidak pada keseluruhan kinerja, melainkan hanya pada indikator nomor tujuh, dalam hal "mengutamakan perolehan hasil kerjamaksimal" yang rendah menurut persepsi responden dengan nilai persentase terkecil. Sedangkan secara keseluruhan sudah baik, terutama pada indikator nomor empatbelas, dalam hal bekerjasama sangat baik.

Dari hasil analisis verifikatif melalui pengujian dengan pendekatan statistik, semua hipotesis yang diajukantelah terjawab berdasarkan fakta empiris.

Hipotesis pertama menunjukkan bahwa pengembangan SDM berpengaruh signifikan terhadap kinerja pegawai PDAM Cabang Majalengka, dibuktikan dengan hasil uji t yang signifikan. Secara logika mudah dipahami karena dengan adanya pengembangan sumber daya manusia yang dikelola dengan baik dan benar, kompetesi pegawai akan meningkat. Bagi pegawai yang baru memasuki masa kerja, pengembangan sumber daya manusia dapat memberikan pengetahuan, keterampilan, wawasan, dan penguasaan kerja yang relevan tugas dan fungsi masing-masing, bahkan didorong untuk mampu beradaptasi dengan budaya kerja yang berlaku di perusahaan PDAM. Bagi pegawai lama, pengembangan sumber daya manusia, baik melalui pendidikan dan pelatihan, penataran, workshop atau jenis pengembangan lainnya akan memberikan bekal pengetahuan baru sesuai dengan 
perkembangan zaman, terutama perkembangan teknologi yang terus berubah ke arah yang makin canggih. Dengan demikian, kinerja pegawai akans emakin baik.

Hasil penelitian verifikatif ini relevan dengan hasil analisis deskriptif yang menyatakan bahwa pengembangan sumber daya manusia berada pada kondisi baik. Selain itu, hasil penelitian membuktikanteori yang dikemukakan Panggabean (2002:51) bahwa pengembangan pegawai lebih berorientasi kepada masa depan dan lebih perduli terhadap pendidikan yaitu terhadap peningkatan kemampuan seseorang (pegawai) untuk memahami dan menginterpretasi pengetahuan dan bukan mengajarkan keterampilan teknis. Artinya, dengan memberikan pemahaman dan interpretasi pengetahuan pegawai akan memiliki kemampuan untuk memecahkan berbagai persoalan kerja yang pada akhirnya kinerja akan meningkat.

Hipotesis kedua membuktikan bahwa budaya kerja berpengaruh signifikan terhadap kinerja pegawai. Hal ini didukung hasil uji hipotesis dengan uji te yang signifikan. Secara logika dapat dipahami, karena dengan budaya kerja yang baik dan kondusif suasana di tempat kerja akan terasa nyaman berdampak pada kejernihan berpikir, fokus pada pekerjaan, dan saling percaya dan saling bantu yang akan memperkuat kerja tim. Melaksanakan tugas di PDAM yang banyak berhadapan dengan pelayanan publik (masyarakat pelanggan), memerlukan sinergi di antara pegawai yang berbeda fungsi. Maka, kemampuan kerja tim yang didasari budaya kerja tinggi sangat dibutuhkan. Dengan demikian, masuk akal apabila budaya kerja berpengaruh terhadap kinerja pegawai.

Hasil analisis verifikatif ini relevan dengan hasil analisis deskriptif yang menyatakan bahwa budaya kerja berada pada kondisi baik. Di samping itu hasil penelitian ini sejalan dengan teori yang dikemukakan Triguno (2004), bahwa budaya kerja adalah suatu falsafah yang didasari oleh pandangan hidup sebagai nilai-nilai yang menjadi sifat, kebiasaan dan kekuatan pendorong, membudaya dalam kehidupan suatu kelompok masyarakat atauorganisasi, kemudian tercermin dari sikap menjadi perilaku, kepercayaan, cita-cita, pendapat dan tindakan yang terwujudsebagai aktivitas kerja atau bekerja. Dengandemikian, budaya kerja dapat mendorong seorang pegawai untuk bekerja lebih baik.

Hipotesis ketiga membuktikan bahwa secara bersama-sama pengembangan sumber daya manusia dan budaya kierja berpengaruh signifikan terhadap kinerja pegawai PDAM Cabang Majalengka. Hasil penelitian ini dibuktikan nelalui hasil uji hipotesis dengan uji $\mathrm{F}$ yang menunjukkan bahwa F hitung lebih besar dari F tabel. Hasil yang diperoleh mudah dipahami, karena secara parsial saja antara pengembangan sumber daya manusia dengan budaya kerja terbukti berpengaruh signifikan terhadap kinerja pegawai, apalagi apabila keduanya digabung secara bersama-sama, tentu saja akan semakin baik.

Dari hasil analisis regresi, diketahui bahwa nilai regresi pengembangan sumber daya manusia lebih besar dibandingkan dengan nilai regresi budaya kerja. Hal ini juga dapat dipahami bahwa pengembangan SDM yang baik dan benar akan berdampak positif kepada aspek-aspek lain selain kinerja pegawai. Antara lain pada budaya kerja, produktivitas kerja, lingkungan kerja, motivasi kerja, professionalisme, kualitas pelayanan, dan bahkan pada iklim dan budaya organisasi, sehingga pengembangan sumber daya manusia mutlak perlu.

\section{PENUTUP}

Dari hasil penelitian tentang pengembangan sumber daya manusia dan budaya kerja terhadap kinerja pegawai PDAM Cabang Majalengka, dapat disimpulkan bahwa secara deskriptif baik pengembangan sumber daya manusia, budaya kerja, maupun kineja pegawai berada pada kondisi baik. Namun masih terdapat kelemahan pada aspek-aspek tertentu yang masih rendah menurut persepsi responden.

Dari hasil analisis verifikatif, pengembangan sumber daya manusia dan budaya kerja baik secara sendiri-sendiri maupun bersama-sama berpengaruh signifikan terhadap kinerja pegawai. Apabila pemegang kebijakan strategis bermaksud memperbaiki ketiga variabel tersebut, disarankan untuk meningkatkan kesadaran pegawai agar mau mengikuti workshop 
secara sukarela; Mendorong pegawai untuk belajar mengatasi kendala kerja; dan mendorong pegawai untuk mengutamakan hasil kerja secaramaksimal.

\section{DAFTAR PUSTAKA}

Dipang, Ludfia, (2013), Pengembangan Sumber Daya Manusia dalam Peningkatan Kinerja Karyawan pada PT. Hasjrat Abadi Manado, 1(3), $1080-$ 1088.

Haromain, (2013), Manajemen Pengembangan Sumber Daya Manusia (SDM) Pondok Pesantren, 1(2), 136149.

Iqbal, Muhamad, (2017), Pengaruh Budaya Kerja Dan Pengawasan Terhadap Kinerja Karyawan (Studi Kasus Di PT Bank DKI Capem Syariah Margonda, Depok), 9(2), 270-280.

Jatmika, Dodik dan Mardiana Andarwati, (2017), Pengaruh Pengembangan Sumberdaya Manusia Terhadap Kinerja Pegawai Melalui Kepuasan Kerja Pegawai Kementrian Agama di Jombang, SENASIF 2017, 395407.

Masirete, Iswan M, (2011), Pengaruh Pengembangan SDM Terhadap Kinerja Pegawai Kantor Camat Menui Kepulauan Kabupaten Morowali, 11(1), 40-48.

Novia,(2017), Strategi Tepat untuk Pengembangan SDM

$$
\text { dalam }
$$

Perusahaan, A-journal.id.id/blog/ 2017. Diaskses; 20 September 2019.

Panjaitan, Maludin, (2017), Pengaruh Pengembangan Sumber Daya ManusiaTerhadap Kinerja Pegawai PT. Indojaya Agrinusa, 3(2), 7-15.

Panggabean, Mutiara S. (2002), Manajemen Sumber Daya Manusia. Jakarta : Ghalia Indonesia

Rahmat Fadhil, Rahmat, M. Syamsul Maarif, Tajuddin Bantacut, dan Aji Hermawan. (2017), Model Strategi Pengembangan Sumber Daya
Manusia Agroindustri Kopi Gayo dalam Menghadapi Masyarakat EkonomiASEAN, 16(2), 141-156.

Sudarman, Enjang, (2018), Pengaruh Budaya Kerja dan Komitmen Organisasi Terhadap Kinerja Pelayanan Publik di Dinas Pariwisata dan Kebudayaan KabupatenKarawang, 5(1), 71-84.

Sunjaya, Oky Pratama Adi, Yulianeu, Budi Leoardo, dan Syaifuddin Tsalis, (2017), Pengaruh Budaya Kerja, Kemampuan dan Komitmen Organisasi Terhadap Kinerja Karyawan Bagian Produksi Pada PT.Phapros.tbk Semarang, 3(3), 17.

Sudarmanto, 2014, Kinerja dan Pengembangan Kompetensi SDM, Yogyakarta: Pustaka Pelajar.

Setiobudi, Eko, (2017), Analisis Sistem Pengembangan SDM MelaluiPendekatan, Training, Studi Pada PT. Tridharma Kencana, 4(1), 45-65. 


\section{BIOGRAFI PENULIS}

Asep Suhada, NIDN. 0414067204. Asisten Ahli, dosen pada Program Studi
Administrasi Publik Fakultas Ilmu Sosial dan Politik Universitas Majalengka.
Mengampu mata kuliah Manajemen SDM, Perbandingan AN, Administrasi Publik
Kontemporer, dan Manajemen BUMN.
Email: denasepberseka7@gmail.com

